\title{
TROPICAL GINGER CULTIVATION IN NORTH AMERICAN TEMPERATE CLIMATES
}

\author{
Michael Bordelon ${ }^{1} \&$ W. John Kress ${ }^{1}$
}

The popularity of gingers, in the family Zingiberaceae and many native to Southeast Asia, is increasing as more species are brought into cultivation by botanists and as botanic gardens increase their public displays in glasshouses and outside beds. Not only are the foliage and flowers striking in appearance with bright colors and unusual forms, but many have medicinal uses as well. Some species are evergreen while others go dormant during the winter months. Gingers are relatively easy to cultivate and are not prone to insect pests. In regions with freezing temperatures during the winter a glasshouse is required. With proper care and planning, a great variety of species can be successfully cultivated and put on view for the public.

\section{INTRODUCTION}

Gingers have been cultivated in the southern United States for over 25 years and for over a century in European countries. They are now gaining popularity as an ornamental pot plant in the northern United States. Not only does the foliage give a tropical feel to a garden but they have some of the most beautiful and intricate flowers found in the plant kingdom (Plate 1). Over 1200 species of gingers have been described in the family Zingiberaceae (Larsen et al, 1998) with more species (Theilade and Mood, 1997; Sakai and Nagamasu, 1998; Poulsen, Mood, and Ibrahim, 1999; Williams, Kress, and Thet Tun, 2002) and even genera (Newman, 1995; Mood and Larsen, 1997; Larsen and Mood, 1998; Sakai and Nagamasu, 2000; Kress and Larsen, 2001; Larsen and Jenjittikul, 2001) being identified and described each year. All are native to Southeast Asia with the exception of Renealmia which is found in Central and South America, and Siphonochilus, Renealmia, Aframomum, and Aulotandra which are found in Africa (Kress et al., 2002). Although the genus Costus and relatives have been included in the ginger family in the past, they are more appropriately placed in their own family, Costaceae (Kress, 1990; Kress et al., 2001; Specht et al., 2001).

Molecular analyses and morphological features suggest that the family can be divided into four subfamilies (Kress et. al., 2002; Plate 2): Tamijioideae, Alpinioideae, Siphonochiloideae, and Zingiberoideae. However, from a horticultural standpoint, the family can be divided into two groups. Tamijioideae and Alpinioideae comprise the first group which are characterized by plants that are evergreen. They do not go dormant and require the same amount of growing space in the winter as they do in the summer. In order to successfully overwinter these when the temperatures drop below freezing, they must be maintained in a warm greenhouse. The second group includes the Siphonochiloideae and the Zingiberoideae that are made up of species that are not evergreen. These plants go dormant naturally or can be forced into a dormant state. The size of the pot is the

${ }^{1}$ Michael Bordelon and John Kress are based at the Department of Botany. Address: Smithsonian Institution, National Museum of Natural History, 10 $0^{\text {th }}$ and Constitution Avenue NW Washington DC 20560. Email:bordelon@si.edu, kress@si.edu 
determining factor in deciding how much space they will need inside during the winter. Care at this time of the year is minimal. This discussion will focus on the latter group of dormant gingers and our experience in cultivating them at the Smithsonian. Our region around the capital city of Washington, D.C., is characterized by hot (often over $35^{\circ} \mathrm{C}$ ) and humid summers with relatively mild winters (averaging $5-10^{\circ} \mathrm{C}$ ) although sub-freezing temperatures and snow occur every year.

\section{HABITAT}

The species of subfamilies Siphonochiloideae and Zingiberoideae will generally not tolerate freezing temperatures. Cautleya and Roscoea which are found in the middle elevations of the Himalayas in southern China, Bhutan, Myanmar and Thailand are a few of the exceptions (Ngamriabsakul et al., 2000). These are winter hardy, but do not thrive in the high heat and humidity of the summers in the Washington area. Zingiber mioga and some species of Alpinia from Japan are both winter hardy and heat tolerant. Other gingers, such as hedychiums can survive mild winters without protection. We have seen a number of these plants over-winter unprotected in outside gardens as far north as Maryland. More experimentation will probably yield a few more hardy species.

Most of the gingers that go dormant come from the monsoonal areas of southern China and east India into Myanmar, Thailand, Laos, Cambodia, and Vietnam (Kress et al., 2002; Wood et al., 2000). Siphonochilus is from the monsoonal areas of Africa. Some species of the 'dormant' genera (e.g., Globba) also grow in peninsular Thailand, Malaysia, and Indonesia, but they generally do not go dormant because they have adapted to pockets of evergreen forest fed by underground springs scattered throughout the monsoon regions (Williams et al, 2004). In cultivation, water can be withheld from these plants thereby forcing them into dormancy. The monsoon rains start in April and end in October. Deciduous trees shed their leaves and the foliage of the herbaceous gingers dry up. It is not uncommon to see the forest floor burning during the dry season. It does not rain again until the following April. Just before the rains come, the trees come into leaf and the spring ephemerals come to life. Kaempferia rotunda, commonly called Asian Crocus in the western world, is one of the first to flower. Included in this group of spring ephemerals are species of Curcuma, Kaempferia, Globba, Hemiorchis, and Gagnepainia.

\section{CULTIVATION}

Nearly all of these plants can be grown in the ground and treated the same way that their close relatives, the Cannas, would be treated. The exceptions are some epiphytic species of Hedychium and Rhynchanthus. Most gingers can be planted in a bed composed of loose organic matter and then dug up and stored for the winter. Growing in a pot is a little different. The period of breaking dormancy generally starts around April and can continue well into June. At this time each plant should be removed from the pot as removing the soil is necessary to examine the condition of the rhizome. All of the species 
that go dormant have thick rhizomes (Plate 3A) or have tubers (swollen roots) either attached closely to the rhizome or hanging down from them. Old shriveled tubers and rhizomes should be removed along with any rotted material. When dividing a plant, try to keep as many tubers attached to the rhizome as possible. Tubers by themselves will not produce a plant as they possess no meristems or buds. Repot the plants at the same depth as when they break dormancy. Pot size is determined by the species, size of the rhizome, and ultimate size required. Gingers like an organic soil that holds water, but is well drained and has an average $\mathrm{pH}$ of around 5.0-7.0. Some species that grow in limestone will tolerate a slightly higher $\mathrm{pH}$. We have been growing them for over ten years and have tried a number of soil mixes. With the variety of bagged soil mixes on the market, it makes little sense to mix your own. Approximately $99 \%$ of our plants are grown in the same mix. This uniformity makes watering much easier, because horticultural staff become familiar with the water retention ability of that soil. The few gingers that are epiphytic can be grown in soil, but will perform much better attached to a piece of wood or grown in bark in a hanging basket.

Every horticulturist knows that each plant is an individual and will dry out at different rates. They have to be checked each day and watered when the top layer of soil is dry. They should not be allowed to dry out completely while they are actively growing. If they do, they may go into dormancy prematurely and will not have enough energy in their rhizomes to come back the following spring. If they do 'bounce back' from being completely dry, they will not look as good for the rest of the growing season and high quality flowering will be greatly reduced. Gravel can be added into the bottom of the pots for extra weight so the plants will not blow over with a strong wind. This practice also aids drainage. Plants are best treated with a liquid fertilizer with an $\mathrm{N}: \mathrm{P}: \mathrm{K}$ ratio of 17:5:17 and additional calcium and magnesium at every watering. A top dressing with 15:9:12 slow release fertilizer and an organic fertilizer can also be applied. This treatment may seem excessive to some, but gingers are heavy feeders and, when grown outside, heavy rains can leach all nutrients out of the soil. Most gingers are reasonably tolerant of the amount of sun they receive and the same species of many genera have been observed in the wild growing in areas from full sun to deep shade. Remember however, they come from a monsoonal area; it is cloudy and raining during most of their growing stage. A plant that is leached in colour, has burned edges and shows signs of stress, such as leaves curling or oriented in a more upright position would most likely appreciate more shade. It is a 'give and take' situation: more sun will give more flowers; more shade will give better foliage. A general rule of thumb is that a tall plant will tolerate more sun than a shorter plant (Larsen et al., 1999). Zingibers, hedychiums, and some curcumas may reach heights of over two meters and can be grown in more sun than most globbas and the low growing kaempferias. Plants in full sun require more water.

The autumn in the northeastern United States corresponds with the end of the monsoon season in Southeast Asia. Temperatures start to drop and the first frosts arrive in mid-October to early November. Most gingers can tolerate a light frost but the rhizome should never be allowed to freeze. The leaves will start to turn yellow when 

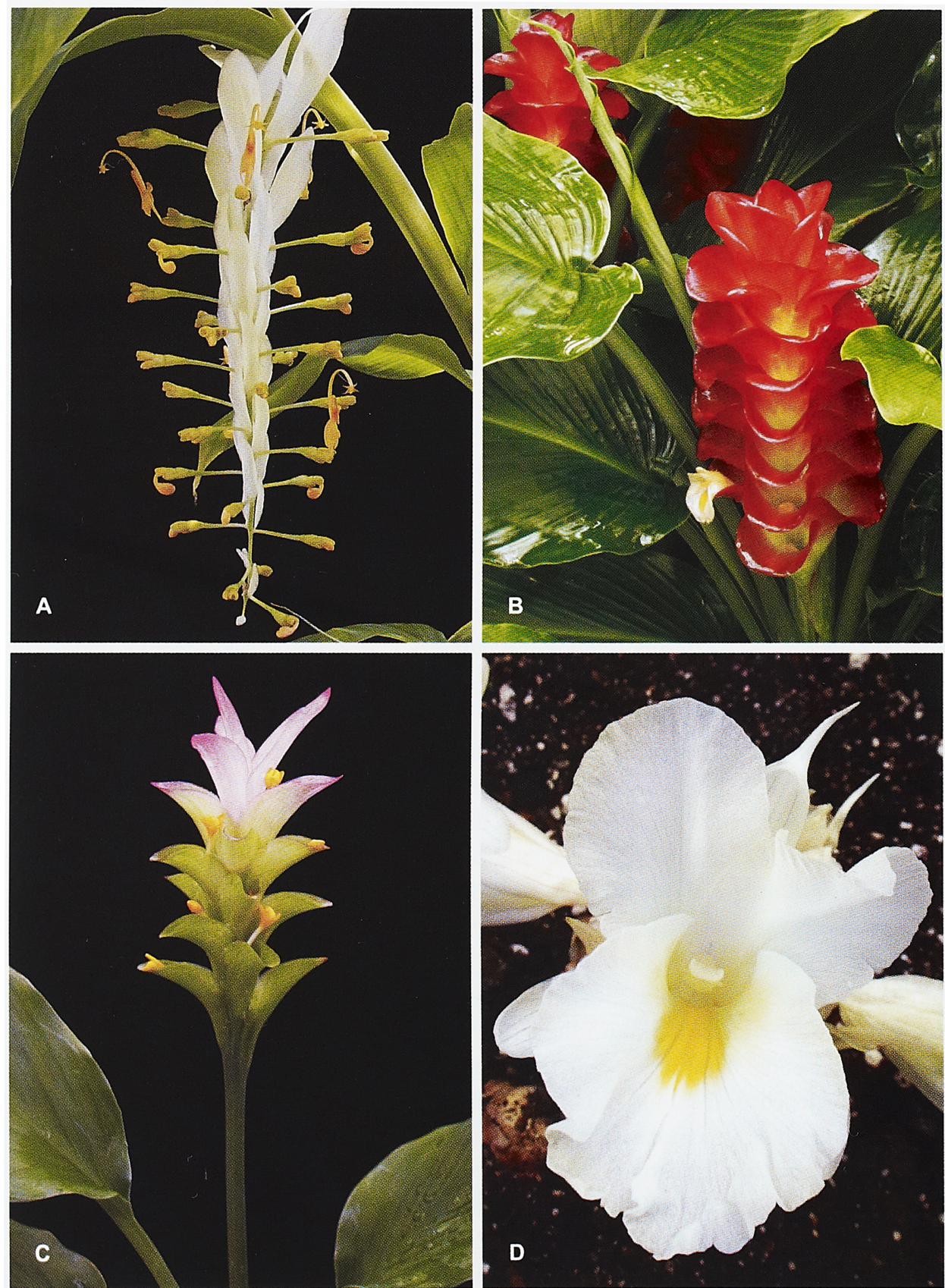

Plate 1. Examples of Zingiberaceae suitable for horticultural use. A. Globba magnifica. B. Curcuma roscoeana. C. Smithiatris myanmarensis. D. Kaempferia candida. 

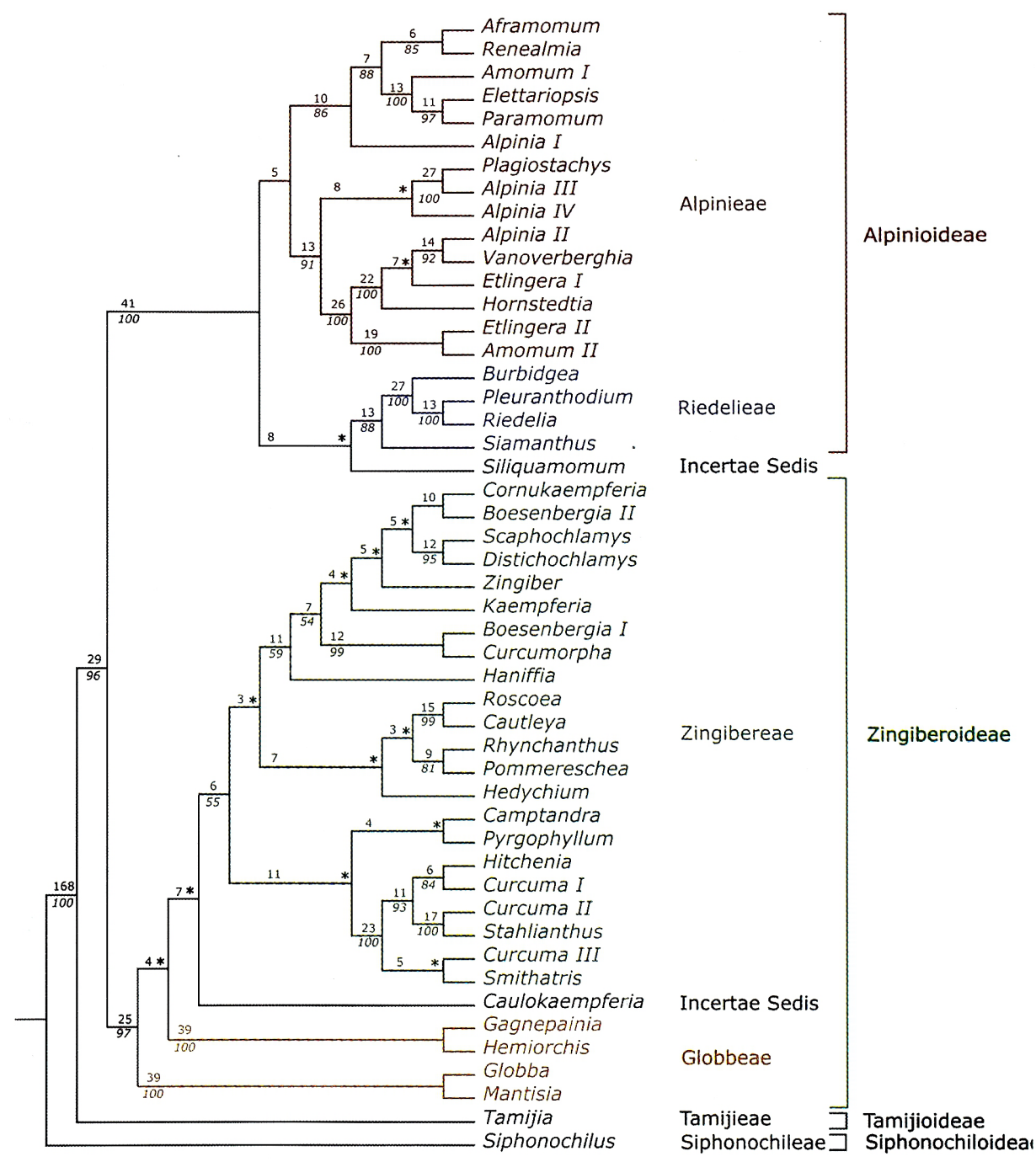

Plate 2. Phylogeny and classification of the family Zingiberaceae (from Kress et al. 2002) 

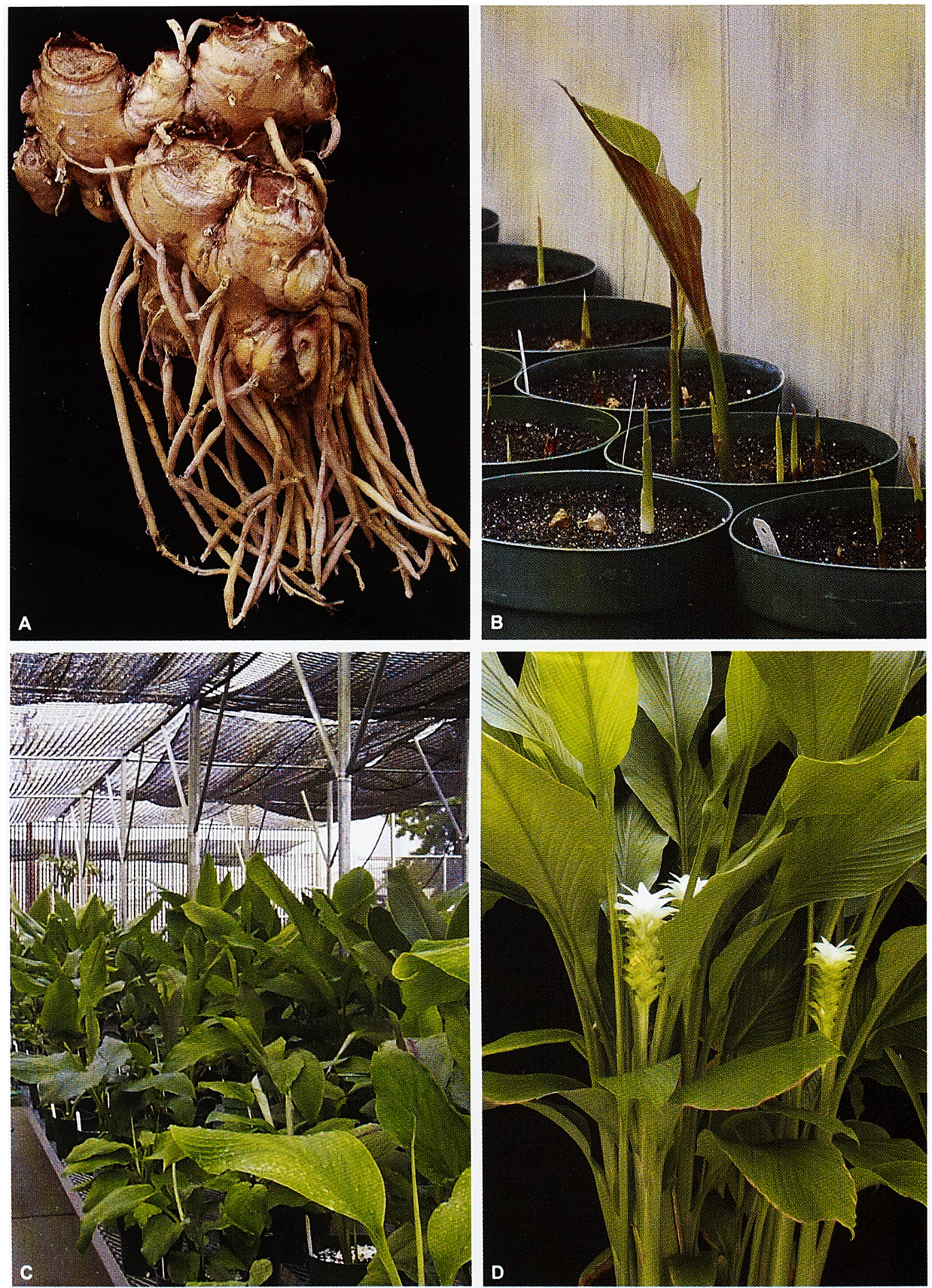

Plate 3. Cultivation of Zingiberaceae. A.Cleaned rhizomes of Zingiber sp. B. Species of Curcuma breaking dormancy in early spring. C. Various species of Zingiberaceae cultivated inpots in a shade house in early spring. D. Curcuma longa in full bloom in a shade house in summer. 
the plant is starting to go dormant. At this point watering should be reduced because the plant does not need as much. The energy in the leaves is being transported to the rhizomes and tubers to support next year's growth. All of the plants should be moved to a frost free area before they are subjected to a hard frost that will destroy the leaves and damage the rhizome. It is not uncommon to see our temperatures drop to $-12^{\circ} \mathrm{C}$ and sometimes lower in the winter. We store our dormant plants in a small heated clear polyhouse where temperatures average around $13-16^{\circ} \mathrm{C}$. These plants have an abscission layer at the base of the petiole and the leaves will naturally fall off when they have completed their cycle. All watering should stop at this point. Continued watering will rot the rhizome. They should be checked occasionally throughout the winter to ensure that they are not becoming too dehydrated. If they appear shriveled, water very lightly, just enough to 'plump' them back up. Moving all of the pots together once the leaves have been removed, not only saves space, but prevents the sun from drying the soil too fast. A translucent plastic covering on the polyhouse will help to reduce the strength of the sun. We use clear plastic because the plants start to break dormancy before the last frostfree day and a well-lit area is needed for good growth before they are moved outside. If plants are being grown without a poly-cover, they can be moved into a dry location and comfortably over-wintered there (Llamas, 2003).

\section{PROPAGATION}

All of the gingers can be divided when they are repotted. Select only healthy hard rhizomes and discard any soft material. The best time to do this is when the plants have just broken dormancy in the spring (Figure 3B). The soil should be kept slightly moist and then watered freely as needed. If the plants have been divided at the end of the growing season, they should be watered once to establish the soil around the rhizome and then allowed to dry out until new growth starts in the spring. Gingers can also be divided while they are actively growing (Figure $3 \mathrm{C}-\mathrm{D}$ ) but the vigour of the plant will be reduced. Some species of Globba produce bulbils in the lower part of the inflorescence and these propagules can be laid on the soil surface where they will produce small plants. Some bulbils need a dry dormant period in the same way that seeds do, and may not start to grow until the following spring. Not many of the gingers produce seed without effective natural or artificial pollinators. Some of the more prolific self-seed producers can be found in the genera Hedychium, Kaempferia, and Siphonochilus. Some Globba, Hedychium, and Zingiber species can also be started from stem cuttings. These cuttings can be laid on the soil and kept moist or rooted upright in a container of water. Plants should be separated from the stem and potted once roots have started to develop (Chapman, 1995). 


\section{PESTS AND DISEASES}

Insects are not much of a problem with gingers that are grown outside. These species, which spend a part of their life cycle in a dormant condition, naturally lose all of their foliage and therefore any associated insect pests once a year. They then start their new growth cycle pest-free. Caterpillars should be removed as soon as possible. They can consume a small plant in a very short time. In our region the Spotted Cucumber beetle, Diadrotica undecimpunctata howardi, has been seen eating the flowers of Curcuma, but has not done significant damage. The European Corn Borer, Ostrinia nubilalis can collapse a stem in a matter of days. Once the borer is spotted, the stem should be removed and discarded. It is important to remove all of the stems when the plant goes dormant. A well-drained soil that does not stay saturated will keep the fungus gnats down. Spider mites are infrequent pests. Removing dead material during repotting will keep fungus and bacterial infections to a minimum.

\section{CONCLUSION}

No 'cookbooks' currently exist for growing gingers and numerous methods have been advocated for successful cultivation. As we gain more experience and experiment with new techniques we are sure to find additional methods to grow these tropical plants. The guidelines provided here will hopefully allow horticulturists to bring a bit of Southeast Asia to botanic gardens and conservatories in temperate climates.

\section{ACKNOWLEDGMENTS}

The authors would like to recognize the following individuals for their assistance and guidance over the years: Ray Baker, Leslie Brothers, Alan Carle, Mark Collins, Kai Larsen, Anders Lindstrom, Ida Lopez, Mark Newman, Tanya Rehse, Kyle Williams, and Tom Wood.

\section{REFERENCES}

CHAPMAN, T. S. 1995. Ornamental gingers, a guide to selection and cultivation. Unpublished.

KRESS, W. J. 1990. The phylogeny and classification of the Zingiberales. Annals of the Missouri Botanical Garden 77: 698-721.

KRESS, W. J., \& K. LARSEN. 2001. Smithatris, A new genus of Zingiberaceae from Southeast Asia. Systematic Botany 26: 226-230.

KRESS, W. J., L. M. PRINCE, W. J. HAHN, \& E. A. ZIMMER. 2001. Unraveling the evolutionary radiation of the families of the Zingiberales using morphological, molecular, and fossil evidence. Systematic Biology 51: 926-944.

KRESS, W. J., L. M. PRINCE, \& K. J. WILLIAMS. 2002. The phylogeny and a new classification of the gingers (Zingiberaceae): evidence from molecular data. American Journal of Botany 89: 1682-1696. 
LLAMAS, K. A. 2003. Tropical flowering plants: a guide to identification and cultivation. Timber Press, Portland

LARSEN, K., AND J. MOOD. 1998. Siamanthus, a new genus of Zingiberaceae from Thailand. Nordic Journal of Botany 18: 393-397.

LARSEN, K., J. M. LOCK, H. MAAS, \& P. J. M. MAAS. 1998. Zingiberaceae. In K. Kubitzki [ed.], The families and genera of vascular plants, vol. IV, 474-495. Springer-Verlag, Berlin, Germany.

LARSEN, K., H. IBRAHIM, S. H. KHAW, AND L. G. SAW. 1999. Gingers of Peninsular Malaysia and Singapore. Natural History Publications (Borneo), Kota Kinabalu.

LARSEN, K., \& T. JENJTTTIKUL. 2001. Laosanthus, a new genus of Zingiberaceae from Laos. Nordic Journal of Botany 21: 135-138.

MOOD, J., AND. K. LARSEN. 1997. Cornukaempfera, a new genus of Zingiberaceae from Thailand. Natural History Bulletin of the Siam Society 45: 217-221.

NEWMAN, M. F. 1995. Distichochlamys, a new genus from Vietnam. Edinburgh Journal of Botany 52: 65--69.

NGAMRIABSAKU, C., M. F. NEWMAN, \& Q. C. B. CRONK. 2000. Phylogeny and disjunction in Roscoea (Zingiberaceae). Edinburgh Journal of Botany 57: 39-61.

POULSEN, A. D., J. MOOD, \& H. IBRAHIM. 1999. Three new species of Etlingera (Zingiberaceae) from Borneo. Nordic Journal of Botany 19: 139-147.

SAKAI, S., \& H. NAGAMASU. 1998. Systematic studies of Bornean Zingiberaceae: I. Amomum in Lambir Hills, Sarawak. Edinburgh Journal of Botany 55: 45-64.

SAKAI, S., \& H. NAGAMASU. 2000. Systematic studies of Bornean Zingiberaceae: III. Tamijia: a new genus. Edinburgh Journal of Botany 57: 245--255.

SPECHT, C. D., W. J. KRESS, D. W. STEVENSON, \& R. DESALLE. 2001. A molecular phylogeny of Costaceae (Zingiberales). Molecular Phylogeny and Evolution 21: 333-345.

THEILADE. I., \& J. MOOD. 1997. Five new species of Zingiber (Zingiberaceae) from Borneo. Nordic Journal of Botany

WILLIAMS, K. J., W. J. KRESS, \& THET TUN. 2002. A striking new epiphytic Hedychium (Zingiberaceae) from Myanmar with a discussion of several anomalous related genera. Edinburgh Journal of Botany 60: 43-48.

WILLIAMS, K. J., W. J. KRESS, \& P. S. MANOS. 2004. Appendages do matter: the phylogeny, evolution and classification of the genus Globba and tribe Globbeae (Zingiberaceae). American Journal of Botany 91: 100-114.

WOOD, T.H., W. M. WHITTEN \& N.H. WILLIAMS. 2000. Phylogeny of Hedychium and related genera (Zingiberaceae) based on ITS sequence data. Edinburgh Journal of Botany 57: $261-270$. 
